\title{
Expression of a Foreign Gene in Four Species of Lepidopterous Insects Using a Baculovirus Vector
}

\author{
Toshihiro Nagamine, Masaaki Kurihara, Shogo Matsumoto \\ and Takashi Mitsui \\ The Institute of Physical and Chemical Research (RIKEN), \\ Hirosawa, Wako 351-01, Japan
}

(Received May 24, 1993; Accepted August 19, 1993)

\begin{abstract}
We prepared a recombinant Autographa californica nuclear polyhedrosis virus by substituting a chloramphenicol acetyl transferase (CAT) gene for the polyhedrin with pAcYMl transfer vector. Cultured cells of Spodoptera frugiperda infected with the recombinant virus revealed high CAT activity after $24 \mathrm{hr}$ postinoculation (pi). The viral titer in the culture medium rapidly increased during 12 to $24 \mathrm{hr}$ pi and then reached to the maximum level. Injection of the recombinant virus into four species of lepidopterous larvae, Spodoptera litura, Bombyx mori, Mamestra brassicae and Pseudaletia separata, evoked an expression of the recombinant CAT gene but with different patterns in each case. Viral growth patterns in the four species suggested that the different multiplication rates of the recombinant virus in each insect affected the gene expression pattern.
\end{abstract}

\section{INTRODUCTION}

Baculoviruses are typical insect pathogens and have long been of interest as biological agents for insect pest control. The most intensively studied baculovirus, Autographa californica nuclear polyhedrosis virus (AcNPV), has a rod-shaped enveloped nucleocapsid carrying a double-stranded DNA genome of $128 \mathrm{kbp}^{1-8)} \mathrm{NPVs}$ produce polyhedral inclusion bodies, which contain a lot of virus particles, in the nuclei of host cells. The inclusion bodies termed polyhedra are stable in environment and serve to spread the infection in the fields. They are proteinous crystals consisting of one major polypeptide, polyhedrin, that is synthesized by high level expression of a late gene during the virus infection. Recently baculovirus vector systems based on the polyhedrin gene promoter have been developed and widely used for efficient expression of foreign genes. ${ }^{3-6)}$ In addition, with the progress of genetic engineering of baculoviruses, studies have been focused on the development of genetically engineered insecticides. $^{7-9)}$

AcNPV has a relatively wide host range in baculoviruses and is pathogenic to at least 10 different families of lepidopterous insects. ${ }^{10}$ ) For a control of insect pests as well as production of a useful protein by using a recombinant AcNPV, it seems important to compare the expression efficiency of a foreign gene among different hosts. In this paper we describe a difference in the expression efficiency of the recombinant chloramphenicol acetyl transferase (CAT) gene among four different insect species. Present results suggest that the different multiplication rate of the recombinant virus in each insect affects the gene expression.

\section{MATERIALS AND METHODS}

\section{Virus and Cells}

Autographa californica nuclear polyhedrosis virus (AcNPV) and Spodoptera frugiperda cell line (IPLB-SF-21AE) ${ }^{11,12)}$ were kindly provided by Dr. H. Mori (Kyoto Institute of Technol- 
ogy, Japan). S. frugiperda cells were grown in TC-100 medium (Gibco) supplemented with $10 \%$ fetal bovine serum and subcultured every 4 to 6 days.

\section{Insects}

Spodoptera litura and Mamestra brassicae were kindly provided by Nissan Chemical Industry Co. and Hokko Chemical Industry Co. respectively and reared on an artificial diet at $28^{\circ} \mathrm{C}$ under a $16 \mathrm{hr}$ light- $8 \mathrm{hr}$ dark condition. Pseudaletia separata and Bombyx mori were reared on artificial diet as described previously. ${ }^{13)}$

\section{Preparation of a Recombinant Virus}

DNA manipulations were carried out essentially as described by Maniatis et al. ${ }^{14}$ ) Transfer vector, pAcYM1, ${ }^{15)}$ was also kindly provided by Dr. Mori. A CAT cartridge ${ }^{16)}$ was excised from pMAM-neo-cat (Clontech) by digestion with SalI and the staggered ends of the cartridge were filled in with T4 DNA polymerase (Takara). The blunt-ended fragment was cloned into SmaI site of pAcYMl and a recombinant clone bearing the cartridge in an appropriate orientation was selected by restriction enzyme analyses. S. frugiperda cells were co-transfected with the vector DNA carrying CAT gene and purified AcNPV DNA as described by Matsuura et al. ${ }^{17)}$ and recombinant polyhedrin-negative viruses were purified by plaque assay. Stocks of the recombinant viruses were stored at $-70^{\circ} \mathrm{C}$ until use.

\section{Infections}

In the case of cultured cells, $1-1.5 \times 10^{6}$ cells of $S$. frugiperda were seeded into $35 \mathrm{~mm}$ culture dishes and incubated for $12-16 \mathrm{hr}$ at $28^{\circ} \mathrm{C}$. After medium was removed, the cell monolayer was inoculated with virus at a multiplicity of 1 plaque forming units (pfu)/cell. After 1-hr adsorption period, the virus inoculum was removed and the inoculated cells were washed three times with medium and then incubated with fresh medium at $28^{\circ} \mathrm{C}$. At appropriate times of postinoculation (pi), cell pellets and culture supernatants were collected separately by centrifugation at $1300 \times g$ for $10 \mathrm{~min}$, and stored at $-70^{\circ} \mathrm{C}$ until $\mathrm{CAT}$ assay or plaque assay.
For the infectious experiments of larvae, newly ecdysed larvae at final instar were injected with $10 \mu \mathrm{l}$ of virus inoculum at $4 \times 10^{6}$ $\mathrm{pfu} / \mathrm{ml}$. Every $24 \mathrm{hr}$ after injection, the inoculated larvae were collected and stored at $-70^{\circ} \mathrm{C}$ until used for CAT assay. Hemolymph was also collected at the same time from each larva and stored at $-70^{\circ} \mathrm{C}$ until plaque assay.

\section{Plaque Assay}

Plaque assay was carried out by the method described previously ${ }^{18)}$ with slight modification. S. frugiperda cells $\left(1-1.5 \times 10^{6}\right)$ were seeded in $35 \mathrm{~mm}$ tissue culture dishes and incubated at $28^{\circ} \mathrm{C}$. After incubation for $12-16$ $\mathrm{hr}$, the medium was removed and an aliquot of $0.2 \mathrm{ml}$ of virus inoculum was applied to the cell monolayer. When hemolymph was used as inoculum, the stored test hemolymph at $-70^{\circ} \mathrm{C}$ was thawed, filtered through a 450-nm Millipore filter and applied to the cell monolayer. After 1-hr adsorption period, the inoculum was discarded and the cells were washed 3 times with fresh medium and overlaid with $2 \mathrm{ml}$ of prewarmed TC-100 medium containing 1\% Seaplaque agarose (FMC Co.). After the medium was hardened at room temperature, further $1 \mathrm{ml}$ of TC-100 medium was overlaid to ensure the nutritional supply and the dishes were incubated for $4-5$ days at $28^{\circ} \mathrm{C}$. Plaques were stained with neutral red and the number was counted.

\section{CAT Assay}

After centrifugation of cultured cells infected with the recombinant virus, the cell pellets were washed twice with phosphate buffer saline and resuspended with $100 \mu \mathrm{l}$ of $0.25 \mathrm{~m}$ Tris$\mathrm{HCl}$ buffer ( $\mathrm{pH} 7.5)$. The cell suspension was frozen and thawed five times reciprocally and then centrifuged at $1300 \times g$ for $10 \mathrm{~min}$. The CAT activity of the resultant supernatant was then determined. As for the CAT activity in the larvae infected with the recombinant virus, frozen larvae (S. litura: 0.2-1.0 g/larva, $B$. mori: $0.9-3.0 \mathrm{~g}, M$. brassicae: $0.2-0.7 \mathrm{~g}, P$. separata: $0.2-0.7 \mathrm{~g}$ ) were crushed in liquid nitrogen and homogenized with a Polytron homogenizer in $5 \mathrm{ml}$ of $0.25 \mathrm{M}$ Tris- $\mathrm{HCl}$ buffer $(\mathrm{pH}$ 7.5). The homogenate was centrifuged and the CAT activity of the resultant super- 
natant was determined. One or five microliters of each test solution was added into 0.25 M Tris- $\mathrm{HCl}$ buffer (final volume, $180 \mu \mathrm{l}$ ) containing $\mathrm{D}$-threo-[dichloroacetyl $\left.-1-{ }^{14} \mathrm{C}\right]$-chloramphenicol (1.85 GBq/mmol, $2 \mu \mathrm{mol}$, Amersham) and Acetyl-CoA $(80 \mathrm{mmol})$. The mixture was incubated at $30^{\circ} \mathrm{C}$ for $30 \mathrm{~min}$ and cooled on ice. Chloramphenicol and its acetylated derivatives were extracted once from the reaction mixture with $1 \mathrm{ml}$ of ethyl acetate and the extract was evaporated in vacuo. The resultant was redissolved in $20 \mu \mathrm{l}$ ethyl acetate and each $2 \mu \mathrm{l}$ aliquot was applied onto TLC plates (Silica gel 60 F254; Merck). On the plates, chloramphenicol and its acetylated derivatives were separated with chloroform: methanol (94:6) and detected by autoradiography.

\section{RESULTS}

\section{Multiplication of a Recombinant Virus in Cultured Cells}

S. frugiperda cells were inoculated with the recombinant AcNPV carrying $\mathrm{CAT}$ gene. At various period after inoculation, both the cell pellets and the culture medium were separately harvested by centrifugation $(1300 \times g)$ of the infected cell suspensions. The cell pellets were subjected to CAT assay and the culture media were employed for titration of virus by plaque assay.

With the mock-infected cells, only intact, non-acetylated, chloramphenicol was found in the autoradiogram of TLC (Fig. 1). With the infected cells, CAT activity was not detected until $12 \mathrm{hr}$ pi and high activity of CAT was found after $24 \mathrm{hr}$ pi (Fig. 1). In the medium where the infected cells were cultured, the viral titer increased rapidly from 12 to $24 \mathrm{hr}$ pi and then gradually reached to the maximum level (Fig. 2). These results indicate that the inserted CAT gene was highly expressed under the control of a late gene promoter, that is, polyhedrin gene promoter.

\section{Expression of CAT Gene in Four Different Species of Lepidopterous Larvae}

Four species of zero-day-old larvae at final instar, S. litura, B. mori, $M$. brassicae and $P$. separata, were injected with $10 \mu \mathrm{l}$ of inoculum at a concentration of $4 \times 10^{6} \mathrm{pfu} / \mathrm{ml}$. The inoculated larvae were sacrificed every $24 \mathrm{hr}$ after

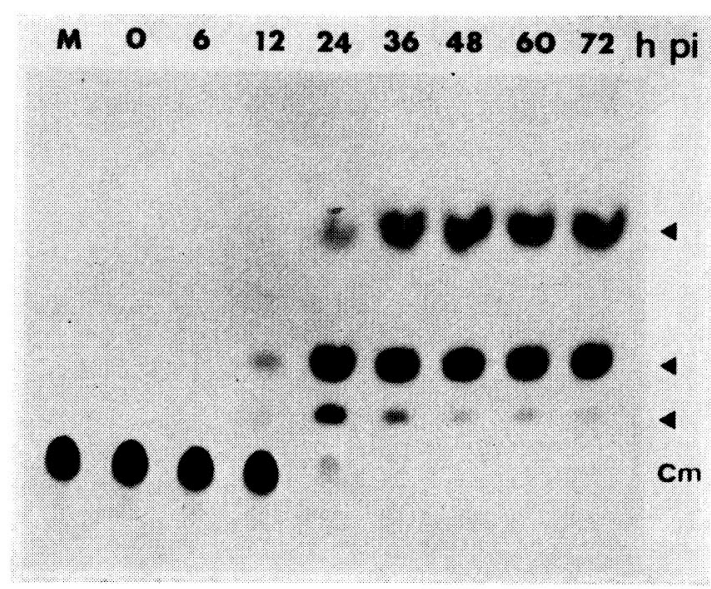

Fig. 1 Autoradiogram of TLC analysis in CAT activities for cultured cells infected with a recombinant AcNPV.

Spodoptera frugiperda cells were inoculated with a recombinant virus bearing the CAT gene at 1 $\mathrm{pfu} / \mathrm{cell}$. The cells were collected at the indicated periods pi and destroyed by repeat of freezing and thawing 5 times. The CAT activity in the cell lysates was assayed with ${ }^{14} \mathrm{C}$-chloramphenicol as a substrate as described in the MATERIALS AND Methods. Cm: chloramphenicol, 4 : acetylated derivatives, $\mathrm{M}$ : mock-infected cells.

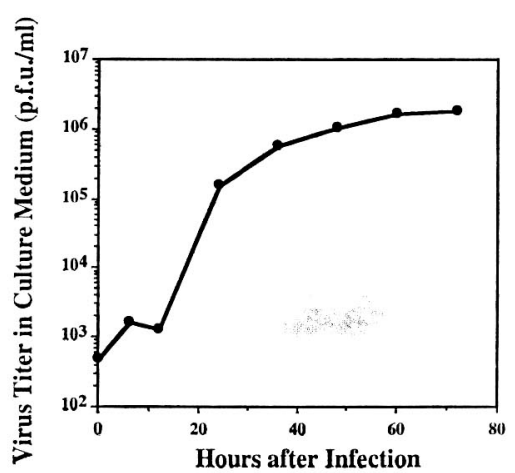

Fig. 2 Growth curve of a recombinant AcNPV in cultured cells.

Spodoptera frugiperda cells were inoculated as in Fig. 1 and the culture medium was collected at the various periods pi. The viral titers in the media were measured by plaque assay as described in MATERIALS AND METHODS.

injection and their CAT activities were measured.

In S. litura larvae infected with recombinant 

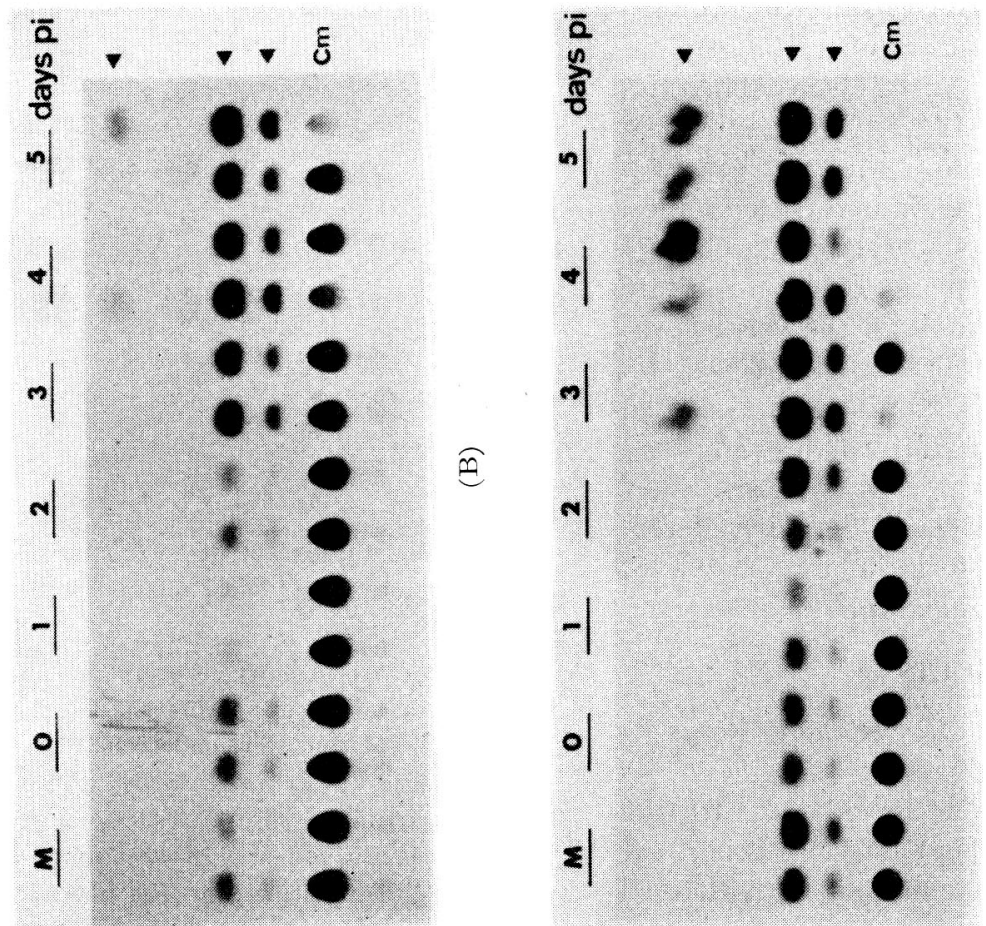

+
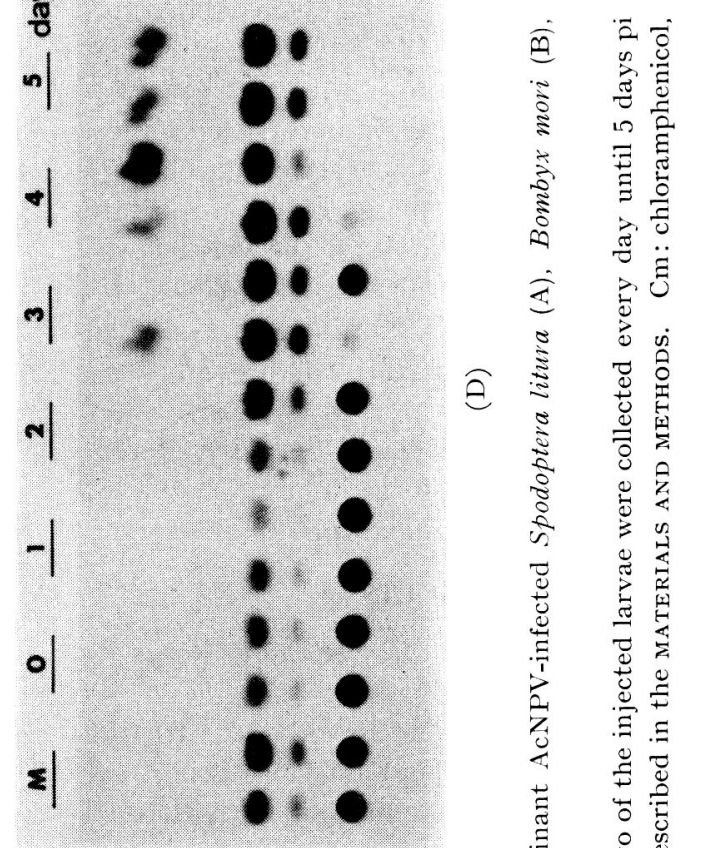

$\widehat{\theta}$

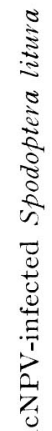
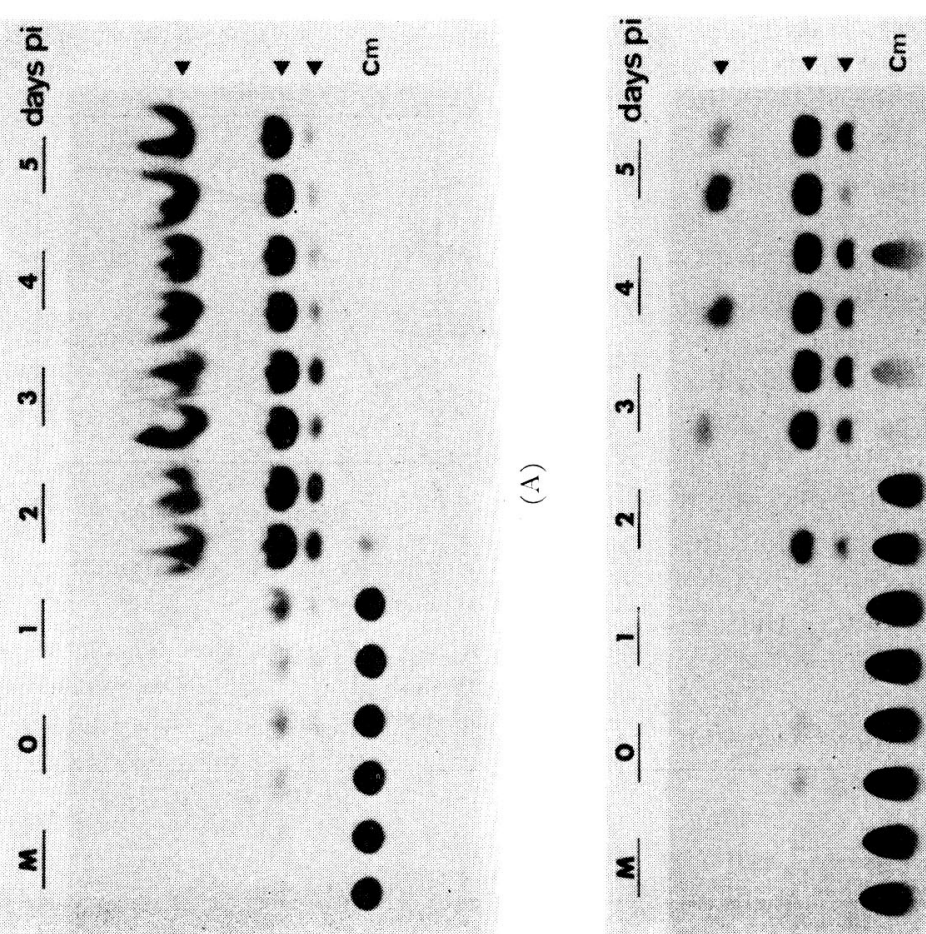
virus, high activity of CAT was found after 2 days pi (Fig. 3A). In B. mori, low endogenous CAT activity was seen in mock-infected larvae and no increase of the activity was seen until 2 days pi in infected larvae (Fig. 3B). Then, the activity increased from 3 days pi but the activity was considerably lower than that in $S$. litura (Fig. 3A and B).

In the case of $M$. brassicae and $P$. separata, expression patterns of CAT gene were similar although the endogenous enzyme activity in $M$. brassicae was higher than that in $P$. separata (Fig. $3 \mathrm{C}$ and $\mathrm{D}$ ). The CAT activities presumably derived from the recombinant virus were detected by 2 or 3 days pi and then high activities were expressed in both species.

\section{Titration of Recombinant Virus in the Hemolymph from Insects}

Since there were differences in the pattern of CAT activity among 4 species tested, we examined the viral titers in the hemolymph by plaque assay.

The viral titer in S. litura increased rapidly within 2 days pi and remained high level as same pattern as in the CAT activity in comparison with those of other 3 species. The titer in B. mori was lower than that in S. litura through the experimental period (Fig. 4). The

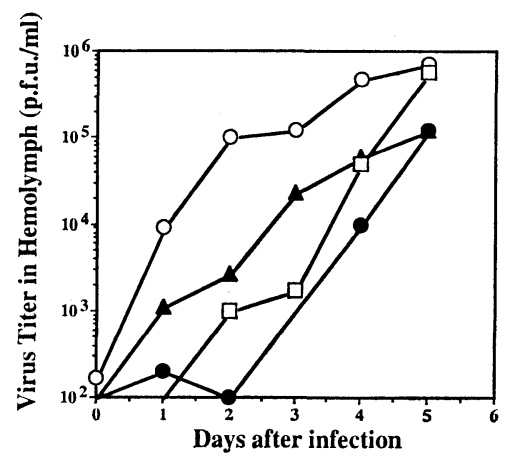

Fig. 4 Multiplication of a recombinant AcNPV in insects.

Zero-day-old larvae at final instar were injected with $4 \times 10^{4} \mathrm{pfu}$ and the hemolymph was collected at various times pi. The viral titer was assayed as described in the MATERIALS AND METHODS. The titer lower than $10^{2} \mathrm{pfu} / \mathrm{ml}$ can not be determined by our method. $\bigcirc:$ S. litura, @: B. mori,

$\Delta$ : M. brassicae, $\square:$ P. separata. viral titer in $M$. brassicae or $P$. separata was intermediate level between $S$. litura and $B$. mori.

\section{DISCUSSION}

Using a CAT gene as a reporter, we examined the efficiency of the foreign gene expression of a baculovirus vector both in cultured cells and 4 different species of lepidopterous insects. CAT gene is widely used for the studies of various promoters because the CAT activity can be assayed easily and only a few organisms are known to produce CAT endogenously. ${ }^{16)}$ In this study, indeed, the cultured cells have no endogenous CAT activity but insects, such as $P$. separata and B. mori, have some activity of CAT (Fig. 3B and D). However, the CAT activity derived from the infection with the recombinant virus bearing the CAT gene was distinguishable from the endogenous activity. We were able to detect the expression of the CAT gene, and the recombinant baculoviruses bearing CAT gene have proved to be of use for a model system of baculovirus expression vectors.

All lepidopterous species used in this study could be hosts against the recombinant AcNPV, which is known to have a relatively wide host range in baculoviruses. ${ }^{10)}$ It has been reported that S. litura and M. brassicae are alternate hosts for AcNPV. ${ }^{10,19)}$ However, it is not clear whether $B$. mori and P. separata are naturally infected per os with AcNPV because infection of larvae was attained by injection of the recombinant virus into their body cavities in this study.

Under the condition employed here, few virus-infected larvae emerged to adults and most larvae died during larval or pupal stage except for Bombyx larvae. About $30 \%$ of the inoculated larvae of $B$. mori emerged and laid eggs. It is unclear whether they were infected with the recombinant virus or not. As shown in Fig. 3B, however, all inoculated Bombyx larvae expressed the viral CAT gene from 3 days pi. These results suggest that even the normally developed larvae of $B$. mori may also have been infected with the recombinant virus but they did not suffer lethal damages. Therefore, there may be a large difference in susceptibility to AcNPV among individuals in $B$. 
mori. We also examined CAT activity in the Bombyx progeny which were generated from the parent(s) previously inoculated with the recombinant AcNPV, but they had no CAT activity derived from the virus (data not shown).

In the case of $M$. brassicae and $P$. separata, the time point when the CAT activity derived from the recombinant virus appeared was different between replicate samples. It is not clear whether the difference was due to the viral multiplication rate in each individual because we could not collect enough amount of hemolymph from individuals for filtration through a Millipore filter by our method.

A baculovirus vector using the promoter of polyhedrin gene is one of the most efficient expression vectors in eukaryotes..$^{2-5}$ A high efficiency of this vector depends on the high promoter activity of the polyhedrin gene. In the present study, the expression efficiency of the CAT gene was different among the host insects but it is still unclear whether promoter activity of the recombinant gene varies in the host species. However, since the CAT gene was expressed with similar pattern as in the viral titer (Figs. 3 and 4), the different efficiency of the gene expression among the 4 species seems attributable to the difference in viral multiplication rate rather than promoter activity. Therefore, for the production of useful proteins or the control of pests, it seems important to choose a good combination of a baculovirus vector and its host in terms of the multiplication rate of the virus in the selected host insect.

\section{REFERENCES}

1) G. E. Smith \& M. D. Summers: Virology 89, 517 (1978)

2) G. E. Smith \& M. D. Summers: J. Virol. 30, 828 (1979)

3) L. K. Miller: Annu. Rev. Microbiol. 42, 177 (1988)

4) Y.C. Kang: Adv. Virus Res. 35, 177 (1988)

5) V. A. Luckow \& M. D. Summers: Biotechnology 6, 47 (1988)

6) S. Maeda: Annu. Rev. Entomol. 34, 351 (1989)

7) B. D. Hammock, B. C. Bonning, R. D. Possee, T. N. Hanzlik \& S. Maeda: Nature 334, 458(1990)

8) M. D. Tomalski \& L. K. Miller: Nature 352, 82 (1991)

9) L. M. D. Stewart, M. Hirst, M. L. Ferber, A. T.
Merryweather, P. J. Cayley \& R. D. Possee: Nature 352, 85 (1991)

10) A. Gröner: "The Biology of Baculoviruses, Vol. 1. Biological Properties and Molecular Biology," ed. by R. R. Granados \& B. A. Federici, CRC Press, Boca, Raton, FL., pp. 178-202, 1980

11) H. Mori, H. Nakazawa, N. Shirai, N. Shibata, M. Sumida \& F. Matsubara: J. Gen. Virol. 73, 1877 (1992)

12) H. Mori, R. Ito, H. Nakazawa, M. Sumida, F. Matsubara \& Y. Minobe: J. Gen. Virol. 74, 99 (1993)

13) S. Matsumoto, A. Fonagy, M. Kurihara, K. Uchiumi, T. Nagamine, M. Chijimatsu \& T. Mitsui: Biochem. Biophys. Res. Commun. 182, 534 (1992)

14) T. Maniatis, E. F. Fritsch \& K. J. Sambrook: "Molecular Cloning," Cold Spring Harbor Laboratory, Cold Spring Harbor, New York, 1982

15) Y. Matsuura, R. D. Possee, H. A. Overton \& D. H. L. Bishop: J. Gen. Virol. 68, 1233 (1987)

16) T. J. Close \& R. L. Rodriguez: Gene 20, 305 (1982)

17) Y. Matsuura, R. D. Possee \& D. H. L. Bishop: J. Gen. Virol. 67, 1515 (1986)

18) T. Nagamine, M. Shimomura, H. Sugimori \& M. Kobayashi: Appl. Entomol. Zool. 24, 235 (1989)

19) S. Maeda, Y. Mukohara \& A. Kondo: J. Gen. Virol. 71, 2631 (1990)

\section{要 約}

バキュロウイルスベクターを用いた外来遺伝子 の4 種の鱗翅目昆虫における発現

永峰俊弘, 栗原政明, 松本正吾, 満井 喬

トランスファーペクター, pAcYM1 を用いて, ポリへ ドリン遺伝子をクロラムフェニコールアセチルトランス フェラーゼ(CAT) 遺伝子に置換した組換光 Autographa californica 核多角体病ウイルスを作製した。この組換え ウイルスをSpodoptera frugiperda 細胞に接種したと ころ，接種後 24 時間には高いCAT 活性が認められた。 培養液中のウイルスタイターは接種後 12 時間から 24 時 間にかけて急激に増加し, その後次第に最高值に達した。 4 種の鱗翅目昆虫, ハスモンョトウ(Spodoptera litura), カイコ (Bombyx mori), ヨトウ (Mamestra brassicae), アワヨトゥ (Pseudaletia separata) に組換えウイルス を接種した場合，いずれの種においてもウイルス由来の CAT 活性が認められたが， 発現様相が種によって異 なっていた。体液中のウイルスタイターの経時変化か ら，組換えウイルスの増殖速度の違いがこの発現椂相の 相違に影響していることが示唆された. 